\title{
Withholding-tax non-compliance: the case of cum-ex stock-market transactions
}

\author{
Thiess Buettner $^{1,2} \mathbb{D} \cdot$ Carolin Holzmann $^{1} \cdot$ Felix Kreidl $^{1} \cdot$ Hendrik Scholz $^{1}$
}

Published online: 30 April 2020

(c) The Author(s) 2020

\begin{abstract}
This paper explores withholding-tax non-compliance in the context of dividend taxation. It focuses on a specific type of stock-market transactions around ex-dividend dates, so-called "cum-ex" trades, which caused considerable revenue losses due to illegitimate tax refunds in Germany and other countries. We use a stylized model of the stock-market equilibrium to analyze the incentives of traders on the German stock market and find that cum-ex trades are only profitable for both buyer and seller in the presence of collusive tax fraud. Our empirical analysis of market data for publicly traded German stocks from 2009 to 2015 confirms that transaction numbers of stocks suitable for cum-ex trades show the expected increase shortly before exdividend dates in the period before the tax refunding was reformed. In line with the collusion hypothesis, effects on stock-market prices are not found.
\end{abstract}

Keywords Tax compliance $\cdot$ Tax evasion $\cdot$ Withholding taxes $\cdot$ Collusion $\cdot$ Tax fraud $\cdot$ Tax refunding $\cdot$ Cum-ex trades $\cdot$ Ex-dividend date $\cdot$ Dividend taxes $\cdot$ Capital gains taxes

JEL Classification H26 · G12

Previous versions of the paper were circulated under the title "Stock Market Behavior on ExDividend Dates: The Case of Cum-ex Transactions in Germany."

Electronic supplementary material The online version of this article (https://doi.org/10.1007/s1079 7-020-09602-9) contains supplementary material, which is available to authorized users.

Thiess Buettner

thiess.buettner@fau.de

Felix Kreidl

felix.kreidl@fau.de

Hendrik Scholz

hendrik.scholz@fau.de

1 FAU (Friedrich-Alexander-Universität Erlangen-Nürnberg), Nürnberg, Germany

2 CESifo, München, Germany 


\section{Introduction}

Withholding taxes are a key instrument to ensure tax enforcement. Also taxation of dividends strongly relies on withholding taxes. In 2015, 23 out of 34 OECD countries levied withholding taxes on dividend income (Milanez 2017). The instrumental role of these taxes for enforcement is obvious in the debate on tax havens (Johannesen and Zucman 2014). In the EU, for instance, the EU Savings Directive requires countries to either engage in an automatic information exchange, or to levy a withholding tax on income of investors which are domiciled in other European countries (Johannesen 2014).

A characteristic of withholding taxes is that the remitter is not the statutory bearer of the tax. This reduces the incentive to evade taxes since the remitter does not directly benefit from evasion. However, the use of withholding taxes shifts the risk of non-compliance to the remitter (Slemrod 2008), and it may happen that taxes are not withheld or not remitted to the tax authorities. A further problem arises since withholding taxes are typically associated with a refundable tax credit: If no taxes have been withheld, tax refunding results in negative taxes. As the infamous case of "missing trader" fraud under VAT shows, non-compliance of the remitter in combination with tax refunding can be highly problematic. Not only do illegitimate tax refunds reduce available public funds, they also exert important negative externalities such as distortions of competition, inequity and income transfers to organized crime (de la Feria 2018).

Recently, withholding-tax non-compliance received public attention in the context of so-called "cum-ex" trades. This involves short trading around ex-dividend dates, where the stock is sold "cum-dividend" before the dividend date but delivered after, i.e., "ex-dividend". Cum-ex trades are designed specifically to obtain refunds of withholding taxes on dividends even though the corresponding tax payment had not been remitted. ${ }^{1}$ These trades have been reported in various countries, including Germany, Austria and Switzerland (Special Investigation Committee 2017, 348 ) and, more recently, Denmark. ${ }^{2}$ The German case stands out both because of the magnitude of revenue losses and because of the length of the period during which these trades were possible. A tentative estimate of tax-revenue losses points at a stunning amount of 7.2 billion euros (Spengel et al. 2017) for the time period between 2005 and 2011 alone. $^{3}$

One explanation for the massive volume of non-compliance in withholding dividend taxation is that traders searching for arbitrage opportunities simply exploited a tax loophole, or, more precisely, a technical defect in the way the withholding tax was being imposed and administered. This view has been featured in some media

\footnotetext{
1 Throughout the paper, the notion of cum-ex trades always refers to trades set up on purpose to obtain an illegitimate tax certificate. Accidental trades that take place around the ex-dividend date are not referred to as cum-ex trades.

2 See New York Times, October 5, 2018, “Where in the World Is Denmark’s \$2 Billion?”.

3 See also Special Investigation Committee (2017), 471.
} 
reports ${ }^{4}$ and it is intuitive, since the traders' quest for arbitrage opportunities can be seen as a sort of discovery process that detects all types of profitable transactions. An alternative explanation is that the profits associated with illegitimate tax refunds incentivized traders to pursue withholding-tax non-compliance as a deliberate act of tax fraud-buyers and sellers collude, set up deals designed to obtain illegitimate tax refunds, and conceal their trades from tax authorities.

If the first explanation is correct, prevention of tax evasion ultimately requires governments to set up proper systems of taxation and administration which eliminate possibilities for tax arbitrage. Since identifying loopholes associated with transnational transactions is quite challenging, governments could introduce mandatory reporting by taxpayers and intermediaries of cross-border tax planning arrangements in order to improve compliance (e.g., Baker 2015). If the second explanation holds, however, despite already tight regulation and supervision of financial markets, tax authorities would need to take further action to make collusion of non-compliant traders more difficult.

Against this background, this paper explores withholding-tax non-compliance involving illegitimate tax refunds in the context of dividend taxation. We analyze the incentives for traders in a stylized theoretical model of the stock-market equilibrium and derive empirical predictions with regard to market prices and transactions. The empirical analysis exploits the German experience as testing ground. More specifically, we test theoretical predictions using daily stock-exchange data for publicly traded German stocks from 2009 to 2015. Our identification strategy distinguishes between stocks with taxable dividends and stocks that pay tax-exempt dividends and compares developments of stock prices and trading volumes around ex-dividend dates before and after the change in the administration of the tax in January 2012.

As we show in this paper, in a stock-market equilibrium characterized by elimination of arbitrage opportunities for German institutional investors, cum-ex trades are only profitable for both buyer and seller if they collude in tax non-compliance. Under collusion, trades should exert no effects on market prices but are reflected in transaction volumes. In accordance with the collusion hypothesis, the empirical results indicate that market-price effects are absent. Yet they confirm higher trading volumes shortly before the ex-dividend date in publicly available transaction data. However, not all stocks paying taxable dividends display the same increases in trading volumes, indicating that cum-ex trades focus on selected stocks. Our identification approach explicitly takes into account that excess trading around ex-dividend dates may arise for a variety of reasons and distinguishes between the specific effects associated with cum-ex trading and excess trading in general.

A large body of literature in public economics has studied tax evasion and noted that it can be effectively reduced by controls such as withholding taxes and thirdparty reporting (e.g., Kleven et al. 2011; Slemrod and Gillitzer 2014). As noted by Slemrod (2008), however, despite the "paramount importance of withholding", noncompliance under withholding taxation is rarely discussed. Yaniv (1988) provides a theoretical analysis that explores determinants of tax evasion under payroll taxation.

\footnotetext{
${ }^{4} C f$. Der Spiegel, July 13, 2009, "Hase und Igel".
} 
Allowing for collusion between employer and employee, Yaniv (1992) shows that tax evasion may actually increase rather than decrease under tax withholding. Madzharova (2013) argues that the corporate profit tax reduces the incentive for the employer to participate in such collusion. Kleven et al. (2016) provide an agency model, where collusion between employer and employee becomes less likely as firm size grows. Hence, firms have a role as "fiscal intermediaries" in facilitating revenue collection.

To the best of our knowledge, this research paper is the first to deal with noncompliance in the context of withholding taxes on dividends. Revenue losses due to illegitimate tax refunds have so far mainly been discussed in the context of VAT (e.g., Keen and Smith 2006). Our paper also contributes to the literature on stockmarket effects of dividend and capital gains taxes (e.g., Elton and Gruber 1970; Kalay 1982; McDonald 2001; Klautke 2008). Haesner and Schanz (2013) explore the effects in the German case, noting high trading volumes around the ex-dividend dates. Whereas the literature has discussed various reasons for abnormal trading volumes around ex-dividend dates (e.g., Lakonishok and Vermaelen 1986; Karpoff and Walkling 1990; Michaely and Vila 1995; Dhaliwal and Li 2006; Akhmedov and Jakob 2010; Haesner and Schanz 2013; Hartzmark and Solomon 2013; Henry and Koski 2017), our paper shows that withholding-tax non-compliance offers a further explanation.

The paper proceeds as follows. Section 2 gives background information on cumex trading. Section 3 provides a theoretical discussion of cum-ex trading in a stockmarket equilibrium and discusses empirical implications. Section 4 describes the data. Section 5 develops the empirical methodology. Section 6 presents the empirical results and Sect. 7 concludes.

\section{Dividend tax withholding and cum-ex trading in Germany}

Dividends $(D)$ of corporations located in Germany are subject to a withholding-tax rate $\left(\tau_{w}\right)$ of $26.4 \% .^{5}$ Under the rules in place until 2011 (see Fig. 1), the withholding $\operatorname{tax}\left(\tau_{w} \cdot D\right)$ was remitted by the dividend-paying corporation, and the shareholder's depository bank was responsible for issuing the tax certificate that entitles fully taxable German investors to a tax credit or a tax refund. The withholding tax is fully credited against any income taxes. ${ }^{6}$ If taxes filed under the income tax are less than the amounted credited for the certified withholding tax, the tax payer receives the net excess in cash.

The fact that the party remitting was not the same as the party issuing the tax certificate facilitated withholding-tax non-compliance: Using so-called cum-ex

\footnotetext{
5 The withholding-tax burden of $26.4 \%$ consists of a $25 \%$ dividend tax plus $5.5 \%$ solidarity surcharge: $(25 \times 1.055) \%=26.375 \%$.

6 This holds regardless of whether the buyer is subject to the personal income tax or to the corporate income tax.
} 
trades, tax refunds were generated even though no taxes were remitted. ${ }^{7}$ Numerous instances of non-compliance have been detected. The Special Investigation Committee, set up by the German Federal Parliament to investigate cum-ex trading, reports 570 suspicious cases for the time period between 2009 and 2011 ( $c f$. Special Investigation Committee 2017, 370). ${ }^{8}$

To illustrate the institutional arrangement, we first consider the case where an owner of a stock sells the stock 2 days before the ex-dividend date. ${ }^{9}$ The German stock-market guidelines require the settlement of a regular trade to be within 2 days after the date of the transaction. ${ }^{10}$ Hence, with a sale 2 days before the ex-dividend date, the stock may be delivered on the ex-dividend date. In this case, the buyer will not receive the net-of-tax dividend payment from the corporation $\left(1-\tau_{w}\right) \cdot D$, but rather the seller of the stock will. In order to ensure correct dividend distribution, a dividend settlement is carried out. The settlement involves a corresponding compensation of the buyer, which is charged to the seller's account. Thus, the net-of-tax dividend is effectively transferred to the buyer. The settlement also ensures that the buyer, not the seller, receives a withholding-tax certificate. As a consequence of the settlement, the buyer receives a "three-part delivery" of the stock: First, the seller delivers the stock ex-dividend. Second, the buyer receives the dividend compensation $\left(1-\tau_{w}\right) \cdot D$. Third, the buyer's depository bank issues the withholding-tax certificate that entitles the buyer to a tax refund in the amount of $\tau_{w} \cdot D$. This procedure is in accordance with the basic aim of the withholding tax: A tax on dividends is withheld and a tax certificate is issued that entitles the shareholder to a tax credit or refund depending on whether or not taxes are imposed at a later stage.

In the above case, the seller actually owns the stock before the sale. In the case of cum-ex trades, however, the seller (in the following, the cum-ex seller) does not own the stock and conducts a so-called short sale. Figure 2 depicts such a trade. The cum-ex seller instigates the trade through a short sale of a stock cum-dividend at price $P_{C U M} 2$ days before the ex-dividend date. This ensures that a delivery on the ex-dividend date and, thus, ex-dividend is in accordance with the stock-market guidelines. ${ }^{11}$ Due to the delivery ex-dividend, the trade triggers the dividend settlement process. Similar to the above case, the cum-ex buyer receives the stock exdividend, a compensation equal to the dividend net of the withholding tax as well as a certificate that entitles the cum-ex buyer to a tax credit. The compensation is

\footnotetext{
7 This practice is not confined to Germany. Interestingly, the Special Investigation Committee of the German Federal Parliament cites a confidential internal report by a bank domiciled outside Germany noting that similar flaws in the administration of the withholding tax exist also in Belgium, France, Italy, Netherlands, Spain, and Switzerland (Special Investigation Committee 2017, 348).

${ }^{8}$ For an assessment of the illegality of cum-ex trades in Germany see Spengel and Eisgruber (2015) as well as Special Investigation Committee (2017), 378.

9 For the following, $c f$. Spengel (2016).

10 See $\$ 7$ I Boerse Frankfurt (2008).

11 German stock-exchange rules require no coverage of the short sale provided delivery is completed on the second day after the date of the transaction ( $\$ 7$ I Boerse Frankfurt 2008), i.e., cum-ex transactions require no stock borrowing. The cum-ex seller covers the short sale by purchasing the stock from a third party on the ex-dividend date upon immediate delivery and concurrently forward the stock to the cum-ex buyer.
} 


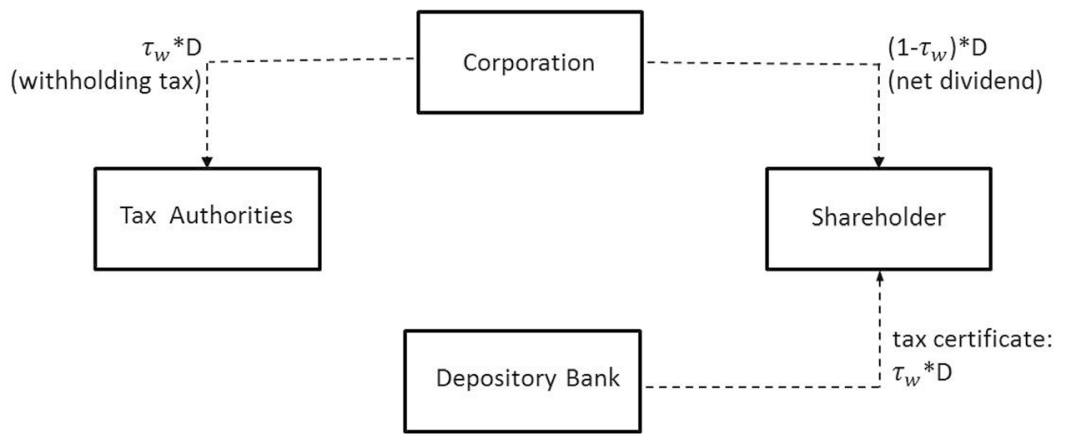

Fig. 1 Dividend tax withholding until 2011. Note $D$ is the dividend and the withholding-tax rate is $\tau_{w}$.

charged to the account of the cum-ex seller. However, the buyer's depository bank does not consider the short-sale nature of the transaction and ignores the fact that the original owner has received not only the net-of-tax dividend but also a withholdingtax certificate. As a consequence, the second certificate de facto entitles the buyer to a refund of taxes that were actually never remitted.

In 2007, the government changed the rules for the dividend withholding tax in order to stop illegitimate tax refunding. To this end, the depository bank of the cumex seller has been made responsible for collecting a tax equivalent to $\tau_{w} \cdot D$ from the cum-ex seller (Special Investigation Committee 2017, 161). However, cum-ex sellers with a foreign depository bank were de facto exempted from this rule. Only those cum-ex trades were prevented from generating an illegitimate tax credit that involved cum-ex sellers with domestic accounts. Transnational cum-ex trades could still lead to illegitimate tax refunds. ${ }^{12}$ Finally, effective in January 2012, the rules for collecting the withholding tax were changed. Since 2012, not the corporations but the banks withhold and remit dividend taxes and are responsible for issuing certificates that entitle the investor to a tax refund. Hence, the party remitting the dividend tax is now the same as the party issuing the tax certificate.

\section{Theoretical analysis}

This section provides a theoretical analysis of the incentives for cum-ex trading. We derive stock-market equilibrium conditions to determine the expected price/drop ratio (PDR), i.e., the price drop on the ex-dividend date in relation to the dividend of a stock. On the ex-dividend date, the owner of the stock is no longer entitled to receive the current dividend. This causes a "technical" drop in the expected price of the stock at the ex-dividend date. Following the literature (Elton and Gruber 1970;

\footnotetext{
12 As a consequence, cum-ex trades with illegitimate tax credits turned international. See Wall Street Journal, October 29, 2014, "European probe widens into tax manoeuvre-Germany-led investigation has recently broadened to involve tax authorities and prosecutors in other countries."
} 


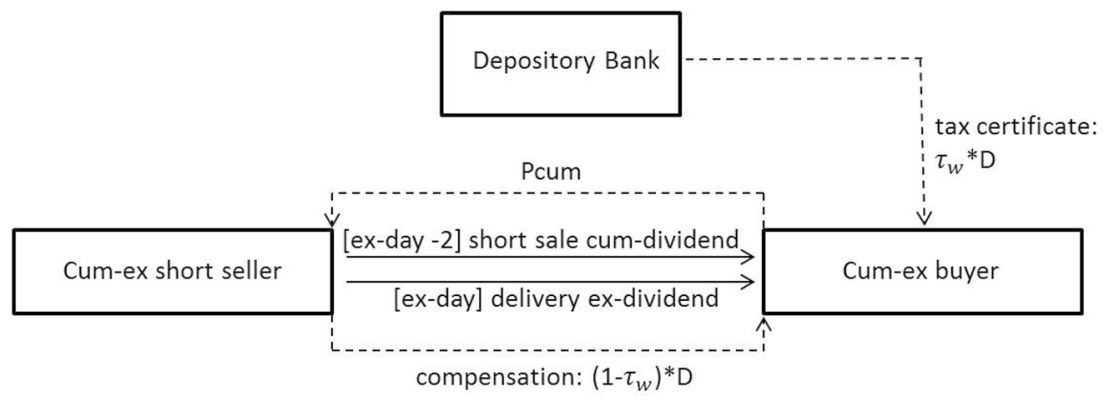

Fig. 2 Cum-ex trades until 2011. Note $D$ is the dividend. The withholding-tax rate is $\tau_{w}$. $P_{C U M}$ denotes the stock price cum-dividend

Kalay 1982; McDonald 2001), we use a costly-arbitrage framework to derive conditions under which risk-neutral investors fail to find arbitrage opportunities-neither buying the stock cum-dividend and selling it ex-dividend (long-arbitrage strategy) nor shorting cum-dividend and closing the short position ex-dividend (short-arbitrage strategy) result in a profit.

\subsection{Stock-market equilibrium}

On the stock market, investors who consider selling the stock meet investors who consider buying the stock. Selling and buying on the stock market each come at transaction cost $c$. Taxation is taken into account by two tax rates, a dividend tax $\tau_{d}$ and a tax on realized capital gains $\tau_{g}$. In view of the tax conditions faced by a fully taxable institutional investor in Germany, which is the testing ground for the empirical analysis, we simplify the exposition and assume that both tax rates are equal to the withholding-tax rate $\tau_{w}=\tau_{g}=\tau_{d \cdot}{ }^{13}$

Consider first an investor following a long-arbitrage strategy, who is buying a stock cum-dividend at the price $P_{C U M}$ and selling the stock ex-dividend at the price $P_{E X}$. The expected return is $\left(1-\tau_{w}\right) \cdot\left(E\left[P_{E X}\right]-P_{C U M}-2 c\right)+\left(1-\tau_{w}\right) \cdot D$ .${ }^{14}$ The long-arbitrage strategy yields an expected return that is smaller than or equal to zero if the expected PDR exceeds or equals a certain threshold, formally, $\frac{P_{C U M}-E\left[P_{E X}\right]}{D} \geq 1-\frac{2 c}{D}$.

An alternative strategy is short arbitrage. This consists of short selling a stock cum-dividend, such that the net dividend is forgone, and purchasing and returning the stock ex-dividend. This strategy yields an expected return of

\footnotetext{
${ }^{13}$ Under the tax law implemented in 2009, this condition applies if the marginal investor is a fully taxable German investor (e.g., Haesner and Schanz 2013).

${ }^{14}$ In accordance with the literature, we assume that the transaction cost is deductible from the capital gains tax base. In the German case, this deduction may or may not be possible. Since the results are not affected by the tax treatment of the transaction cost, we stick to the conventional formulation of the problem.
} 
$\left(1-\tau_{w}\right) \cdot\left(P_{C U M}-E\left[P_{E X}\right]-2 c\right)-\left(1-\tau_{w}\right) \cdot D$. The expected return is non-positive, if $\frac{P_{C U M}-E\left\lfloor P_{E X}\right]}{D} \leq 1+\frac{2 c}{D}$.

The two inequalities allow us to derive a condition that ensures the absence of profitable arbitrage trading opportunities for common investors around ex-dividend dates. This holds if the PDR is within the interval

$$
1-\frac{2 c}{D} \leq \frac{P_{C U M}-E\left[P_{E X}\right]}{D} \leq 1+\frac{2 c}{D} .
$$

\subsection{Cum-ex trading}

In this subsection, we explore the incentives for cum-ex trading in a market equilibrium where the PDR is in accordance with inequality (1). In the first step, we analyze the profit opportunities of short seller and buyer separately in the stock-market equilibrium without illegitimate tax refund. ${ }^{15}$ In the next step, we explore the profit opportunities if the buyer receives an illegitimate tax refund. In a third step, we explore the profit opportunities under collusion.

\subsubsection{The short seller}

The stock is sold cum-dividend at the price $P_{C U M}$ and delivered at the ex-dividend date, when it is traded at price $P_{E X}$. The transaction cost is $2 c$. The short seller is obliged to pay a compensation in the amount of the net-of-tax dividend $\left(1-\tau_{w}\right) \cdot D$ to the buyer. The short seller's expected profit from the trade is:

$$
\Pi_{S}=\left(P_{C U M}-E\left[P_{E X}\right]-2 c\right)-\left(1-\tau_{w}\right) \cdot D
$$

The short seller holds the short position in the stock until the ex-dividend date. Hence, the larger the price drop, the more favorable is the price development from the short seller's perspective. Given inequality (1), the maximum expected price drop in the stock-market equilibrium is $P_{C U M}-E\left[P_{E X}\right]=D+2 c$. In this case, the short seller earns a profit in the amount of $\tau_{w} \cdot D$. More generally,

$$
\tau_{w} \cdot D-4 c \leq \Pi_{S} \leq \tau_{w} \cdot D .
$$

Therefore, in the stock-market equilibrium described by inequality (1), provided the transaction cost is small, a trade would result in a positive profit for the short seller. Importantly, this holds only with taxable dividends, where $\tau_{w}>0$. In the special case of tax-exempt dividends $\left(\tau_{w}=0\right)$, the short seller never obtains a positive profit, as $-4 c \leq \Pi_{S} \leq 0$.

\footnotetext{
${ }^{15}$ Without loss of generality we abstract in the following from the taxation of the profits of traders and focus on the gross earnings of short seller and buyer.
} 


\subsubsection{The buyer's profit without tax refund}

The buyer purchases the stock cum-dividend at the price $P_{C U M}$ and receives the stock ex-dividend at a value of $P_{E X}$. For simplicity, we assume that the buyer immediately sells the stock and realizes the price $P_{E X}$. In addition, the buyer has a transaction cost of $2 c$. As a compensation for forgoing the net dividend, the buyer receives $\left(1-\tau_{w}\right) \cdot D$ from the short seller. The buyer's expected profit is:

$$
\Pi_{B}=\left(1-\tau_{w}\right) \cdot D-\left(P_{C U M}-E\left[P_{E X}\right]+2 c\right)
$$

Since the buyer holds a long position in the stock until the ex-dividend date, the smaller the price drop, the more favorable is the price development from the buyer's perspective. Given inequality (1), the minimal expected price drop in the stock-market equilibrium is $P_{C U M}-E\left[P_{E X}\right]=D-2 c$. In this case, the buyer expects a profit of $-\tau_{w} \cdot D$. More generally,

$$
-\tau_{w} \cdot D-4 c \leq \Pi_{B} \leq-\tau_{w} \cdot D .
$$

Therefore, in the stock-market equilibrium, the buyer incurs a loss. Even in the special case of a tax-exempt dividend with $\tau_{w}=0$, the buyer expects a profit of $-4 c \leq \Pi_{B} \leq 0$. As such trading never results in a positive profit for the buyer, the buyer has no incentive to participate. Furthermore, the maximum profit for the short seller is equal to the buyer's minimal loss. Therefore, the short seller cannot compensate the buyer without making a loss. More generally, regardless of the PDR, $\Pi_{S}+\Pi_{B} \leq 0$.

\subsubsection{The buyer's profit with illegitimate tax refund}

The buyer's incentive to participate in a trade may change, if the buyer receives an illegitimate refundable tax credit of $\tau_{w} \cdot D$. We assume the buyer has a cost of noncompliance $\kappa_{B} \cdot D$ with $\kappa_{B} \geq 0$. This captures efforts to reap the tax credit or to get a refund, the risk of denial and possible prosecution because of tax evasion. The buyer's expected profit with an illegitimate tax refund is:

$$
\Pi_{B}^{n}=\tau_{w} \cdot D+\left(1-\tau_{w}\right) \cdot D-\left(P_{C U M}-E\left[P_{E X}\right]+2 c\right)-\kappa_{B} \cdot D
$$

Still, the smaller the price drop, the larger the profits are. Inserting the minimal expected price drop according to inequality (1) yields a maximum profit for the buyer with illegitimate refund in the amount of $-\kappa_{B} \cdot D$. More generally,

$$
\Pi_{B}^{n} \leq-\kappa_{B} \cdot D
$$

Hence, in the standard arbitrage equilibrium, even if an illegitimate tax refund is obtained, the trading between short seller and buyer would result in a loss for the buyer, if there is some cost associated with claiming the tax refund. If there are no costs and no uncertainty associated with the illegitimate tax refund, the buyer's profit is zero. 


\subsection{Collusion}

In the above setting, while the short seller would make a profit, even a buyer that receives an illegitimate tax refund has no gain and incurs the cost and risk associated with the refund. Given this asymmetric distribution of profits, mutually profitable cum-ex trading requires that the short seller shares some part of the profit with the buyer. To explore the possibilities for profitable collusion, we sum the agents' expected profit functions, Eqs. (2) and (6). As the buyer obtains an illegitimate tax credit, sharing profits requires short seller and buyer to collude and, thus, to commit joint tax fraud. Because joint fraud may be fraught with difficulties due to potential conflict between participants, moral concerns or mistakes (Kleven et al. 2016), or because of different legal consequences in case of detection, the cost of non-compliance is likely to increase under collusion. ${ }^{16}$

We, therefore, subtract the term $\kappa_{C} \cdot D$, with $\kappa_{C} \geq 0$, and derive the expected total profit from collusion:

$$
\Pi_{C}=\Pi_{B}^{n}+\Pi_{S}-\kappa_{C} \cdot D=\tau_{w} \cdot D-\left(\kappa_{B}+\kappa_{C}\right) \cdot D-4 c
$$

This equation shows that the joint profit is positive only as long as $\tau_{w}>\left(\kappa_{B}+\kappa_{C}\right)+\frac{4 c}{D}$. Hence, the two parties have an incentive to collude, if the tax refund is larger than the total costs of collusion, non-compliance and transaction. Importantly, this requires that $\tau_{w}>0$. There is no profitable collusion with stocks whose dividends are tax exempt with $\tau_{w}=0 .{ }^{17}$

\subsection{Empirical implications}

The theoretical discussion enables us to make predictions as to how cum-ex trades may affect the stock market in an arbitrage equilibrium.

First, in order to obtain an illegitimate tax certificate through the settlement process, the cum-ex trade needs to be in accordance with stock-exchange rules. Depending on the trading venue, the short sale would have to take place on specific days before the ex-dividend date of a stock. This implies that transaction volumes of stocks used for cum-ex trades are greater on these days than otherwise.

Second, unlike the short sale of stocks before the ex-dividend date, the transaction volumes reported on the stock market at the ex-dividend date or later may be unaffected. To see this, note that at or after the ex-dividend date there is no need to use specific modes of transaction to ensure a dividend settlement. Traders may

\footnotetext{
${ }^{16}$ In the German tax law, if the tax credit is fabricated using a collusive deal, tax payers and participating parties face an increased risk that their transaction will be classified as tax evasion (42 AO) such that they are prosecuted for a tax offense $(370 \mathrm{AO})$. That this risk is material is illustrated by the currently 499 penal proceedings pending on German courts (see German government's press conference from September 4, 2019).

17 Note that the profit under collusion is independent of the actual magnitude of the PDR. Therefore, the condition for profitability of collusion also holds if the actual PDR differs from one. If the PDR is sufficiently lower than one, however, such trades could be mutually profitable also without collusion if the buyer receives an illegitimate tax refund.
} 
therefore choose among alternative options, including repurchase transactions or securities lending, to ensure that the stock can be delivered ex-dividend. In fact, in the typical arrangement, after all transactions associated with a cum-ex trade are completed, the final owner of the stock is identical to the original owner (Special Investigation Committee 2017, 75). In order to ensure a full circle of transactions, cum-ex trades involve the participation of at least three agents: the cum-ex seller, the cum-ex buyer and the original owner. To deliver the stocks after the ex-dividend date, the cum-ex seller obtains the stock from the original owner. The cum-ex buyer, however, transfers the stock back to the original owner. To conceal transactions, as is noted by the Special Investigation Committee of the German Federal Parliament, cum-ex trades might involve further intermediaries (Special Investigation Committee 2017,440$)$. However, by including the original owner, the agents can ensure that it is not required to access the market to clear positions. This precludes price effects from the fabricated purchases and, importantly, helps to avoid major risks associated with a change in prices.

Third, the circular trading is a possible structure for cum-ex trades, because these trades generate profit from an illegitimate tax rebate and not from a change in ownership. A change in the original ownership of a stock is not required and would only increase risk. But since actual market demand and supply of the stock are not changed, cum-ex trades will not affect the market prices of stocks around ex-dividend dates.

Further predictions could be made if additional assumptions are imposed regarding the cost of non-compliance for the buyer $\kappa_{B}$ and the cost of collusion $\kappa_{C}$. If costs differ between stocks or dividend events, for instance, cum-ex trades would tend to focus on those stocks and events where these costs are low and/or where dividends and tax refunds are high. Moreover, as it may become increasingly difficult to conceal the tax fraud, these costs may be increasing in the absolute volume of tax refunds or in the volume of tax refunds relative to total withholding taxes collected at a stock's dividend date. As a consequence, there might be limits to cum-ex trading. In an equilibrium, in which no further profitable collusion is possible, cum-ex trades are then likely to focus on stocks of large companies or on dividend dates where several corporations pay dividends. However, detailed information is not available in the German case as to how withholding taxes, remittances and tax refunds actually have been monitored and checked by the tax authorities. We can only speculate about the precise determinants of differences in the costs of non-compliance and collusion. If these costs differ between stocks and events-and since also the potential profits differ - the effects of cum-ex trades on the transaction volumes are likely different. This calls for an analysis of the heterogeneity of transaction effects among stocks and events. This is important in particular for providing estimates about the magnitude of cum-ex trading. As potential observable dimensions behind differential effects on transaction volumes, the dividend yield and the market capitalization come into mind. The former determines the amount of refunded taxes and, hence, the potential profits of cum-ex trading. The latter is likely important for the probability of detection as stocks with higher levels of market capitalization often show higher transaction volumes, anyway. 
An implication of the collusive nature of cum-ex trades is that transactions are likely to avoid the anonymous regular order book. As noted above, cum-ex trades are often implemented as circular trades, which implies that there is no need to buy stocks from unrelated third parties. However, the choice of the trading platform is not unrestricted, since the short sale needs to trigger the official settlement procedure in order to generate a tax certificate. One potential option to meet these criteria is to use "midpoint" orders, which are entered in a closed order book and executed at the midpoint of the bid/ask price in the regular (open) order book in accordance with the principle of volume/time priority. This means that even large orders can be executed without moving market prices. Another form that is possibly suited for cum-ex trading are "block trades" where cum-ex seller and buyer coordinate their offers and trade large orders at market-compliant conditions. However, it is also likely and has been noted in the proceedings of the Special Investigation Committee, that cum-ex trades involve "over-the-counter" (OTC) transactions (e.g., Special Investigation Committee 2017, 447).

\section{Data}

The empirical analysis explores the effects of cum-ex trading on PDRs and the number of stocks traded. The focus is on German stocks that were constituents of the HDAX index between 2009 and $2015 .{ }^{18}$ We restrict attention to this time period in order to ensure a stable tax environment for the empirical analysis: Since 2009, Germany applies a flat tax system for capital income taxation.

In the empirical analysis, we focus on regular dividend payments and gather information on dividend payments as well as ex-dividend dates. We do not explore effects of capital bonuses and special dividends occurring on other dates. For each of the 829 regular dividend events in the data, information on the withholding-tax liability of dividends was collected, based on the official dividend announcements of German corporations, published in the business disclosures of the Federal Gazette (Bundesanzeiger).

Our main data source is Thomson Reuters EIKON. Stock prices and number of traded stocks are based on XETRA, which is the primary trading platform in Germany. XETRA prices are the most liquid and also used as reference prices for other trading venues. We use XETRA-based daily unadjusted closing prices and total returns for stocks to calculate ex-dividend date PDRs. XETRA trading volume covers continuous trading, auctions, internalizing activity, block trading as well as midpoint trading. However, the types of transactions underlying the trading volumes are not reported in the XETRA data.

German stock-exchange rules, including the 2-days-settlement requirement, standardly apply for XETRA trades. ${ }^{19}$ Hence, we expect cum-ex trades to occur

\footnotetext{
${ }^{18}$ The HDAX index includes the 110 German stocks that are largest in terms of their free-float market capitalization. It covers approximately $90 \%$ of the market capitalization of the German stocks listed in the broader CDAX.

${ }^{19}$ For settlement procedures on German stock exchanges, see the website of Clearstream, a central securities depository based in Luxembourg.
} 
within a 2-day window before the ex-dividend date of a stock. To analyze the effects of cum-ex trading on trading volume, we use information on the daily number of stocks traded in the years 2009 to 2015 . Table A.1 in Appendix provides descriptive statistics for the data set.

XETRA is the most important trading system, covering approximately $60 \%$ of the regular trading activity of German stocks (Gomber 2015). However, since it is likely that cum-ex traders find other trading venues more attractive, cum-ex trading may be more prevalent on other trading venues. Moreover, not all trades that take place through the XETRA system are actually reported in the standard XETRA data. In particular, over-the-counter (OTC) trades implemented via XETRA are reported in XETRA-OTC data. With OTC, the 2-days-settlement requirement might not apply. ${ }^{20}$ Nevertheless, cum-ex traders may actually want to follow standard settlement rules in order to conceal the tax fraud. To test whether the empirical predictions for the effects of cum-ex trades on trading activity before the ex-dividend date hold for OTC we also use XETRA-OTC data on the number of stocks traded. But because XETRA-OTC uses XETRA prices as a reference point, our analysis of price effects focuses on XETRA.

Cum-ex trades may also show up in the number of stocks traded after the ex-dividend date, when traders clear their positions. But it seems unlikely that these trades occur on XETRA, since settlement on XETRA is not immediate. With regard to XETRA-OTC, different settlement rules may be used, but cum-ex traders may want to follow standard settlement rules in order to conceal the tax fraud, even though other settlement rules may be applicable.

\section{Methodology}

In the light of the theoretical analysis, our empirical analysis explores developments of stock prices and number of trades around dividend dates. We expect cumex trades to show up in high trading numbers 1 or 2 days before the ex-dividend date. With respect to prices, we do not expect effects of cum-ex trading. However, a large body of the literature suggests that tax motivated trading and dividend capturing strategies can explain higher trading activity around ex-dividend dates and exert price effects (e.g., Lakonishok and Vermaelen 1986; Karpoff and Walkling 1990; Michaely and Vila 1995; Dhaliwal and Li 2006; Akhmedov and Jakob 2010; Haesner and Schanz 2013; Hartzmark and Solomon 2013; Henry and Koski 2017). To distinguish these explanations from cum-ex effects, we basically rely on difference-in-difference estimates, which exploit changes in the administration of the withholding tax over time as well as differences in the tax treatment of dividends.

\footnotetext{
${ }^{20}$ Rau (2010), for instance, states that any settlement date (e.g., "T $+3,4,5 \ldots$...) can be agreed for overthe-counter transactions.
} 
Differences over time result from a change in the administration of the withholding tax in January 2012. In the time period until 2011 - in the following referred to as "cum-ex period"- cum-ex trades may have resulted in illegitimate tax credits and refunding of unpaid withholding taxes. This is not the case in the period from 2012 to 2015-referred to as "post period"-since the tax administration was changed. ${ }^{21}$ According to the German tax law, dividends paid from firms' current profits are subject to a $26.4 \%$ withholding tax. Dividends paid from firms' capital reserves are tax exempt. ${ }^{22}$ These differences in the tax treatment of dividends allow us to test whether differences between stocks with taxable dividends in the cum-ex period compared to stocks with tax-exempt dividends are absent in the post period.

The basic specification to test for cum-ex effects on trading numbers is:

$$
\begin{aligned}
\log \mathrm{N}_{i, t}= & \sum_{d=-10}^{10} \lambda_{d} D_{i, d}+\sum_{d=-10}^{10} \omega_{d} D_{i, d} \cdot I_{i}+\sum_{d=-10}^{10} \Lambda_{d} D_{i, d} \cdot T_{i} \\
& +\Omega_{-2} D_{i,-2} \cdot I_{i} \cdot T_{i}+\Omega_{-1} D_{i,-1} \cdot I_{i} \cdot T_{i} \\
& +\beta_{0}+\beta_{1} I_{i}+B_{0} T_{i}+B_{1} I_{i} \cdot T_{i}+\varepsilon_{i, t}
\end{aligned}
$$

The dependent variable, $\log \mathrm{N}_{i, t}$, is the natural logarithm of the number of stocks traded on days before and after dividend event $i .^{23} t$ is defined as a day within a 131day window $(t \in\{-65 ; 65\})$ around the ex-dividend date of a stock with $t=0 . D_{i, d}$ is an indicator that has unit value on the day $d(d \in\{-10 ; 10\})$ before and after the ex-dividend date of event $i . I_{i}$ is a binary indicator that equals unity in the case of taxable dividends and zero in the case of tax-exempt dividends. $T_{i}$ is another binary indicator that takes value unity for dividend events during the cum-ex period from January 2009 to December 2011. $\varepsilon_{i, t}$ is an error term.

To capture the time period immediately before and after the ex-dividend date, the specification includes forward and lagged terms of the ex-dividend date. The basic specification takes account of effects 10 days before and after the ex-dividend date. $\left(\lambda_{d}\right)_{d=-10, \ldots, 10}$ are parameters that capture general differences between trading volumes on days close to the ex-dividend date compared to other trading days. They reflect any deviation of trading numbers around the ex-dividend date for reasons unrelated to the tax treatment. $\left(\Lambda_{d}\right)_{d=-10, \ldots, 10}$ capture a differential development on these days during the cum-ex period. $\left(\omega_{d}\right)_{d=-10, \ldots, 10}$ control for differences in trading volumes of stocks with taxable dividends on each day in the 21-day window around the ex-dividend date. $\beta_{0}$ is a constant term, and $B_{0}$ allows for a deviation

\footnotetext{
21 So-called cum-cum trades have been restricted more recently, i.e., on January 1, 2016. Hence, these trades were possible in the cum-ex period as well as in the post period and, therefore, do not interfere with our identification strategy, which exploits differences in the tax treatment of cum-ex trades before and after January 1, 2012.

22 Dividends paid out of a corporation's capital reserves are withholding-tax exempt according to the German Corporation Tax Act $(\$ 27 \mathrm{KStG})$. At the time of the stock sale, the withholding-tax-free dividend reduces the initial purchasing price of the stock and, thereby, increases the investor's capital gain.

23 To check for robustness, we have used the actual trading volume in euros as dependent variable and obtained similar findings. The results also proved robust against dropping stocks with low trading numbers. The results are available upon request.
} 
from the constant during the cum-ex period. $\beta_{1}$ and $B_{1}$ measure the average difference between taxable and non-taxable dividend paying stocks on ordinary trading days in all years and in the cum-ex period, respectively.

The key parameters of interest are $\Omega_{-2}$ and $\Omega_{-1}$. They indicate whether stocks suited for cum-ex trades do, in fact, show increased transactions on the 2 days before the ex-dividend date-in the time period during which illegitimate tax credits were obtained. More precisely, they capture the difference in trading volumes between stocks with taxable and stocks with tax-exempt dividends on the 2 days before the ex-dividend date in the cum-ex period compared to the post period.

As discussed above, we expect to find stocks with taxable dividends in the cumex period to show higher trading numbers on the last 2 days before the ex-dividend date, i.e., $\Omega_{-2}>0$ and $\Omega_{-1}>0$. Specification (9) tests for differences in the trading numbers of stocks with taxable dividends in the cum-ex period only on the last 2 days before the dividend date and not on other days before or after. The analysis below provides test statistics showing that this restriction is confirmed by the data.

To estimate Eq. (9), we apply pooled OLS as well as panel regressions with dividend-event effects. These effects are specific to each dividend event and, in contrast to company-specific effects, capture differences in the dividend policy of a company over time. This is important, since the basic regression does not include the determinants of the dividend policy and, hence, might be biased due to confounding effects. By including event-specific random and fixed effects we also provide results which capture or even condition on all possible determinants of the decision regarding the dividend policy. ${ }^{24}$ This includes also shocks associated with the Euro crisis. ${ }^{25}$ From an econometric perspective, biases may also arise due to confounding announcement effects. However, because of the decision process involving the boards and the shareholders assembly, the announcement of the dividend by the HDAX firms is typically made before the actual ex-dividend date. Information about the dividend, including whether it is taken from the capital reserves, is therefore given in the period around the ex-dividend date. We also estimate an enriched form of a random-effects model that allows us to study potential heterogeneity in cum-ex trading between dividend events. This so-called mixed linear model allows for random intercepts for each dividend event and event-specific cum-ex effects. These effects capture event-specific deviations from the average cum-ex effects $\left(\Omega_{-2, i}\right.$ and $\left.\Omega_{-1, i}\right)$.

Besides analyzing the number of stocks traded, we also explore the effects of cum-ex trading on the ex-dividend date price drop. To this end, we focus on the price drop between dividend date and ex-dividend date for all dividend events. Formally, we use the following cross-sectional specification:

$$
\begin{aligned}
\mathrm{PD}_{i}= & \gamma_{1} \operatorname{Div}_{i}+\gamma_{2} \operatorname{Div}_{i} \cdot I_{i}+\Gamma_{1} \operatorname{Div}_{i} \cdot T_{i}+\Gamma_{2} \operatorname{Div}_{i} \cdot I_{i} \cdot T_{i} \\
& +\beta_{0}+\beta_{1} I_{i}+B_{0} T_{i}+B_{1} I_{i} \cdot T_{i}+u_{i}
\end{aligned}
$$

\footnotetext{
${ }^{24}$ Note that the event-specific effects nest also stock-specific effects.

25 In fact, the data display a general decline in the numbers of stock traded. Removing the 10 days around the ex-dividend dates, the average daily number of stocks traded in the estimation sample is $1101907,901900,1070403,928000,800838,773031,819035$ in the years from 2009 to 2015.
} 
The dependent variable, $\mathrm{PD}_{i}$, is the drop in the stock price from the dividend date (day -1$)$ to the ex-dividend date (day 0$)$ in euros for each dividend event. ${ }^{26}$ The dividend, $D i v_{i}$, is the dividend in euros. As above, $I_{i}$ is a binary indicator that equals unity in the case of taxable dividends and zero in the case of withholding-tax-free dividends. $T_{i}$ is unity for dividend payments in the cum-ex period from January 2009 to December 2011 and otherwise zero. $u_{i}$ is an error term.

The baseline price/drop is captured by $\gamma_{1} \cdot \gamma_{2}$ tests for differences between taxable and tax-exempt dividends. $\Gamma_{1}$ captures differences in PDRs in the cum-ex period compared to the post period. To study the effect of cum-ex trading on stock prices, we are interested in the coefficient $\Gamma_{2}$ which captures differences in the PDR of stocks paying taxable dividends during the cum-ex period compared to the post period. Due to collusion between cum-ex seller and buyer, we do not expect an effect of cum-ex trading on stock prices and, hence, $\Gamma_{2}=0 . \beta_{1}, B_{0}$ and $B_{1}$ allow for deviations from the constant for the two groups and time periods.

\section{Empirical results}

\subsection{Numbers of stocks traded}

Descriptive evidence on the time pattern of trades is provided in Fig. 3. It depicts the daily average total number of stocks traded for a 131-day window around stocks' ex-dividend dates (ex-dividend dates normalized to zero) as reported in the XETRA data. The trading volumes are separately shown for stocks with taxable dividends (black lines) and stocks with tax-free dividends (gray lines), both for the cum-ex period (solid lines) and the post period (dashed lines). In the case of taxable dividends for the cum-ex period, the figure shows that the average total number of stocks traded increases substantially by approximately $200 \%$ in the last 2 days before the ex-dividend date and immediately drops back to normal levels after the ex-dividend date. Interestingly, this pattern arises in the cum-ex period and not in the post period. No noticeable increases are indicated for events with tax-exempt dividends.

Table 1 presents results for the parameters of interest obtained from various alternative specifications following Eq. (9). It reports estimates for the 2 days before the ex-dividend date in the cum-ex period $\left(\Omega_{-2}, \Omega_{-1}\right)$ and the baseline effects for these days $\left(\omega_{-2}, \omega_{-1}\right)$ for taxable dividends. Table A.2 in Appendix provides the estimation results also for all other parameters. Column (1) reports estimates from a simple OLS specification. The point estimates of 0.487 and 0.238 indicate increases in the number of stocks traded on days -2 and -1 in the cum-ex period. A joint test of the cum-ex effects indicates that the absence of higher trading numbers can be rejected

\footnotetext{
26 To prevent bias due to market developments, we adjust the cum-price by the expected daily return according to Elton et al. (2005). The expected daily return is estimated using a market model. The estimation period covers a time window of 131 days around the ex-dividend date, where 10 days before and 10 days after the ex-dividend date are excluded.
} 


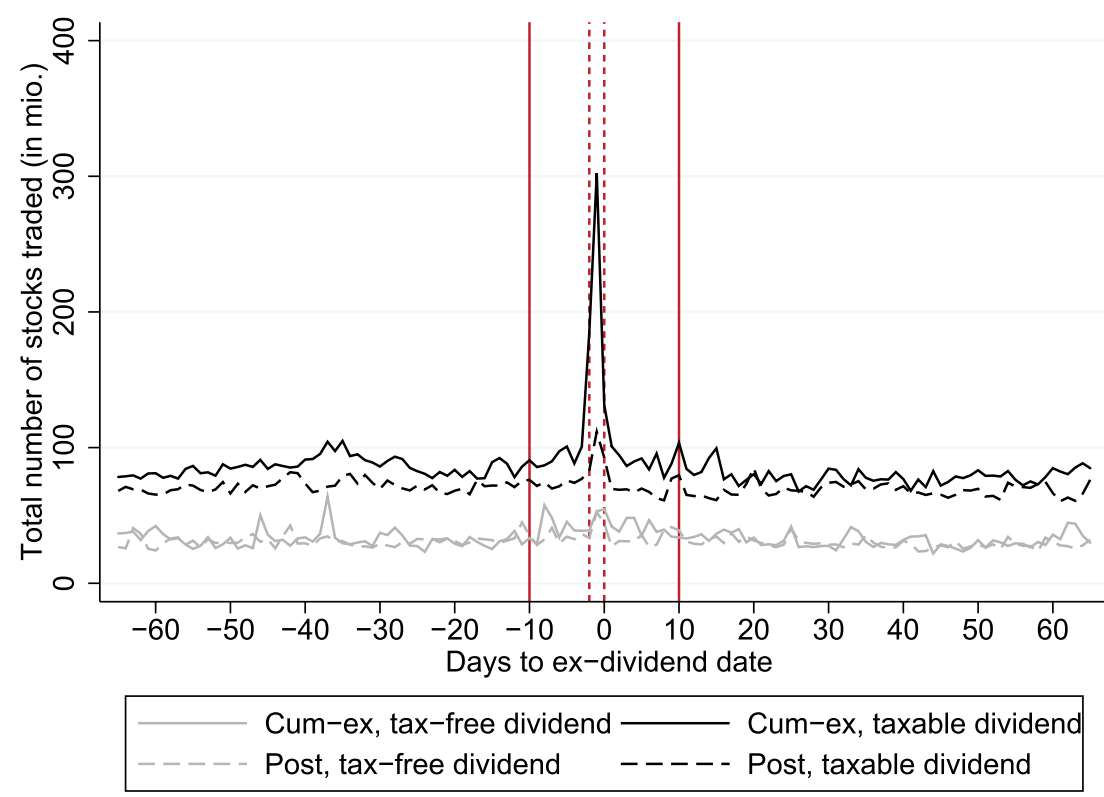

Fig. 3 Daily average total number of stocks traded (XETRA data, 2009-2015). Note This figure depicts the daily average total number of stocks traded as reported in the XETRA data. Dividends paid from current profits are subject to withholding tax (taxable dividends) and, therefore, suitable for cum-ex trading. Dividends from capital reserves are withholding-tax free (tax-free dividends) and, thus, not suitable for cum-ex trading. The trading volumes are separately presented for stocks with taxable dividends (black lines) and stocks with tax-free dividends (gray lines), both for the cum-ex period from 2009 to 2011 (solid lines) and the post period from 2012 to 2015 (dashed lines). The vertical dashed lines mark a 2-day window prior to the ex-dividend date. The vertical solid lines mark the 21-day trading window around the ex-dividend date. Data source: Thomson Reuters EIKON.

at a $10 \%$ level of significance. However, the effects on the 2 days before the ex-dividend date are imprecisely estimated with large standard errors.

Column (2) of Table 1 reports coefficients resulting from an event-level fixedeffects estimation. This specification reports significant effects. The point estimates of 0.256 and 0.324 indicate increases in the number of stocks traded on days -2 and -1 , respectively. Column (3) shows results from a random-effects regression. Though the estimates of the parameters of interest in columns (2) and (3) are almost identical, a formal Hausman test ${ }^{27}$ rejects the null hypothesis that random effects estimates are consistent for all estimated parameters. Hence, we follow Mundlak (1978) and allow for some correlation between unobserved factors and regressors. More specifically, we extend the regression equation with the averages of the timevarying variables (Mundlak terms) in the random-effects specification. Column (4) shows that the results are not affected.

\footnotetext{
27 We employ a heteroskedastic- and cluster-robust version of the Hausman test as suggested in the literature (e.g., Arellano 1993; Wooldridge 2002).
} 
Table 1 Regression results: number of stocks traded around ex-dividend date

(1)

(2)

(3)

(4)

(5)

\begin{tabular}{llllll}
\hline $\begin{array}{l}\text { Cum-ex period } \\
D_{i,-2} * I_{i} * T_{i}\end{array}$ & 0.487 & $0.256^{*}$ & $0.258^{*}$ & $0.258^{*}$ & 0.253 \\
& $(0.30)$ & $(0.15)$ & $(0.16)$ & $(0.16)$ & $(0.15)$ \\
$D_{i,-1} * I_{i} * T_{i}$ & 0.238 & $0.324 * * *$ & $0.324^{* * *}$ & $0.324 * * *$ & $0.316^{* * *}$ \\
& $(0.15)$ & $(0.11)$ & $(0.11)$ & $(0.11)$ & $(0.11)$ \\
Baseline effects & & & & & \\
$D_{i,-2} * I_{i}$ & 0.018 & -0.021 & -0.021 & -0.021 & -0.021 \\
& $(0.08)$ & $(0.07)$ & $(0.07)$ & $(0.07)$ & $(0.08)$ \\
$D_{i,-1} * I_{i}$ & 0.061 & 0.054 & 0.054 & 0.054 & 0.054 \\
& $(0.07)$ & $(0.07)$ & $(0.07)$ & $(0.07)$ & $(0.08)$ \\
Estimation method & OLS & OLS(FE) & GLS(RE) & GLS(RE) & ML(ME) \\
Mundlak terms & - & - & - & Yes & Yes \\
$P$ value cum-ex effects & 0.10 & 0.01 & 0.01 & 0.01 & 0.01 \\
$P$ value other days & 0.83 & 0.25 & 0.24 & 0.24 & 0.24 \\
Variances random effects & & & & & \\
Random effect $D_{i,-2} * I_{i} * T_{i}$ & - & - & - & - & 0.102 \\
Random effect $D_{i,-1} * I_{i} * T_{i}$ & - & - & - & - & 0.273 \\
Random intercept & - & - & - & - & 5.288 \\
\hline
\end{tabular}

The dependent variable is the natural logarithm of the traded number of stocks as reported in the XETRA data. The sample includes all German stocks that are constituents of the HDAX index between 2009 and 2015. It includes 103,386 observations for 806 dividend events by 155 firms. Due to missing values not all 829 dividend events in the data are included. $D_{i, d}$ takes a value of unity on day $d$ before or after the ex-dividend date. $I_{i}$ is a binary indicator that equals unity in the case of taxable dividends and zero in the case of withholding-tax-free dividends. $T_{i}$ is a binary indicator that takes value unity for observations during the cum-ex period from January 2009 to December 2011, and zero in the post period, i.e., in the years 2012 to 2015 . Regression coefficients result from pooled OLS regressions (column (1), fixed-effects (column (2)) and random-effects regressions (columns (3) to (5)). Specification (5) allows for event-specific deviations from the average cum-ex effect on days -2 and -1 (random slopes). The variances of the random intercept and slope effects are reported at the bottom of the table. The employed estimation method, ordinary least squares, without (OLS) and with fixed effects (OLS(FE)), generalized least squares (GLS(RE)) with random effects, or mixed effects maximum likelihood (ML(ME)), and the use of Mundlak terms in random effects regressions are noted in the table. Cluster-robust standard errors (clustered at dividend-event level) are in parentheses. Asterisks denote statistical significance at the 0.01 (***) and $0.10(*)$ levels

Across the different panel model specifications (columns (2) to (4)), the point estimates consistently indicate that the number of stocks traded is increased by cumex trading on day -2 by around $29 \%$ (point estimates of the regression of 0.256 to 0.258 ) and on day -1 by $38 \%$ (point estimate 0.324 ) during the cum-ex period. ${ }^{28}$ Apart from the cum-ex period, we do not find any statistically significant effects

\footnotetext{
${ }^{28}$ In the log-linear model, the predicted cum-ex effect on trading numbers based on the point estimate (in \%) is defined as $\left(\exp \left\{\widehat{\Omega}_{d}\right\}-1\right) \cdot 100$.
} 
in the trading numbers around the ex-dividend date, and the point estimates for the baseline effects are close to zero.

In accordance with the theoretical predictions, the basic specification (9) tests for cum-ex effects only on the last 2 days before the ex-dividend date. As reported in Table 1, joint tests enable us to reject deviations from the baseline time pattern on other days within the 21 days time window around the ex-dividend date at reasonable levels of significance (see $P$ value other days).

Compared with the large spike in the total number of stocks traded in Fig. 3 which points to a $200 \%$ increase, the magnitudes of the point estimates of the cumex effects ( $29 \%$ and $38 \%$ on days -2 and -1 , see above) seem rather small. A possible explanation for the difference between the descriptive evidence and the model results is that not each stock with taxable dividends is used for cum-ex trading, as the basic specification implicitly assumes. Following the theoretical analysis, it makes sense to argue that the costs of non-compliance and collusion as well as the value of the tax refund vary between dividend events. As a result, cum-ex effects will be heterogeneous. To study the heterogeneity in cum-ex effects between different events, we estimate an enriched random-effects model that incorporates event-specific random effects for days -2 and -1 . Column (5) of Table 1 reports results. The mean cum-ex effects of this model, $\widehat{\Omega}_{-2}$ and $\widehat{\Omega}_{-1}$, are similar to the above results.

Figure 4 shows the empirical distribution of the predicted cum-ex effects in $\%$ for days -2 and $-1 .^{29}$ The figure reports the distribution of the cum-ex effects based on the point estimate of the mean cum-ex effect $\widehat{\Omega}_{d}$ and the event-specific predictions of the random day effect $\widehat{\Omega}_{d, i}$. It shows that there is substantial variation in cum-ex effects between events. In particular, the distributions are skewed and show long tails on the right-hand side. This indicates that there are some dividend events where the number of trades increases by much more than suggested by the average cum-ex effects. In fact, some events are predicted to show an increase in the number of stocks traded by more than $100 \%$. On day -1 , we even find increases of more than $200 \%$.

While the above results are obtained using XETRA data which captures the majority of transactions on the XETRA trading venue, over-the-counter trades are not covered. To see whether similar patterns can be found specifically for these types of transactions, we ran a set of regressions using XETRA-OTC data. The results are reported in Table 2. Across specifications, the results point to a strong increase in transactions before the ex-dividend date. Unlike with the XETRA data, no effect is found 2 days before and excess trading is concentrated on the last day before the ex-dividend date. Interestingly, the magnitude of this effect is much stronger than above: The point estimates indicate an increase of $304 \%$ on the last day before the ex-dividend date. Strong heterogeneity is also found in this case. Using a mixed effects model, the average effects are similar, but the results point to substantial variances.

${ }^{29}$ The event-specific prediction of the cum-ex effect on day $d$ in $\%$ is $\left(\exp \left\{\widehat{\Omega}_{d}+\widehat{\Omega}_{d, i}\right\}-1\right) \cdot 100$. 


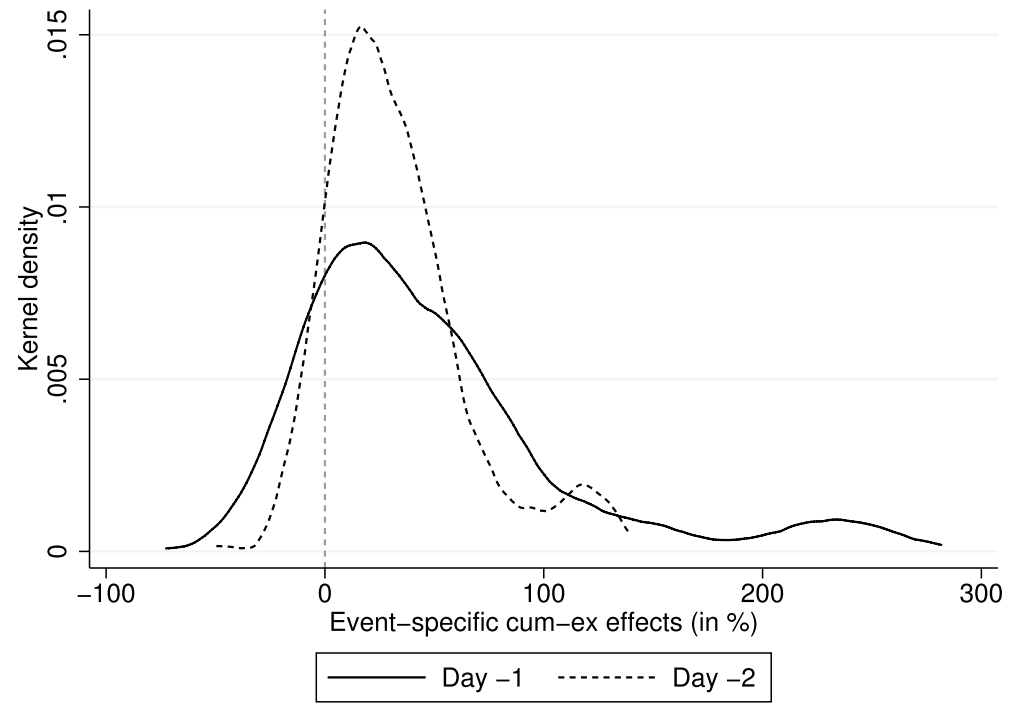

Fig. 4 Prediction of event-specific cum-ex effects. Note The graphs depict kernel-based estimates of the distributions of predicted event-specific cum-ex effects for days -1 (solid line) and -2 (dashed line) obtained by the mixed-linear model (see column (5) in Table 1). The event-specific prediction of the cum-ex effect in $\%$ is $\left(\exp \left\{\widehat{\Omega}_{d}+\widehat{\Omega}_{d, i}\right\}-1\right) \cdot 100$. Epanechnikov kernel densities

\subsection{Ex-dividend date price/drop ratios}

Having explored effects on the number of stocks traded, this section reports tests of the theoretical prediction that, due to collusion, cum-ex trades do not affect stockmarket prices. Descriptive evidence on the PDRs is provided in Fig. 5. It reports kernel-based estimates of the distribution of price/drop-ratios in the cum-ex period separately for stocks with dividends subject to withholding taxes and for those with tax-exempt dividends. Both distributions are largely overlapping with mean PDRs close to one. This suggests that cum-ex trading has had little effect on the PDRs, as the distributions are clearly centered around unity.

Regression results following Eq. (10) are provided in Table 3. With regard to the actual magnitude of the PDR, it is interesting to note that the point estimates suggest a PDR of around unity. Provided the marginal trader is a fully taxable German institutional investor, this is consistent with the standard arbitrage equilibrium outlined in Sect. 3. In fact, statistical testing does not allow us to reject a unit PDR (see $P$ values noted at the bottom of the table). More importantly, however, the interaction terms with taxable dividends in the cum-ex period are very small and not significantly different from zero. Thus, our empirical results do not enable us to reject the theoretical prediction that collusive cum-ex trades have no stock-market price effects on the ex-dividend date. 
Table 2 Regression results: number of stocks traded via XETRA-OTC around ex-dividend date

(1)

(2)

(3)

(4)

(5)

\begin{tabular}{llllll}
\hline Cum-ex period & & & & & \\
$D_{i,-2} * I_{i} * T_{i}$ & -0.008 & 0.109 & 0.107 & 0.107 & 0.070 \\
& $(0.36)$ & $(0.34)$ & $(0.34)$ & $(0.34)$ & $(0.34)$ \\
$D_{i,-1} * I_{i} * T_{i}$ & $1.408^{* * *}$ & $1.397 * * *$ & $1.396^{* * *}$ & $1.396^{* * *}$ & $1.320^{* * *}$ \\
& $(0.41)$ & $(0.39)$ & $(0.39)$ & $(0.39)$ & $(0.39)$ \\
Baseline effects & & & & & \\
$D_{i,-2} * I_{i}$ & 0.164 & 0.133 & 0.133 & 0.133 & 0.133 \\
& $(0.21)$ & $(0.20)$ & $(0.20)$ & $(0.20)$ & $(0.20)$ \\
$D_{i,-1} * I_{i}$ & 0.268 & 0.354 & 0.352 & 0.352 & 0.352 \\
& $(0.26)$ & $(0.25)$ & $(0.25)$ & $(0.25)$ & $(0.25)$ \\
Estimation method & OLS & OLS(FE) & GLS(RE) & GLS(RE) & ML(ME) \\
Mundlak terms & - & - & - & Yes & Yes \\
$P$ value cum-ex effects & 0.00 & 0.00 & 0.00 & 0.00 & 0.00 \\
$P$ value other days & 0.02 & 0.00 & 0.00 & 0.00 & 0.00 \\
Variances random effects & & & & & \\
Random effect $D_{i,-2} * I_{i} * T_{i}$ & - & - & - & - & 1.479 \\
Random effect $D_{i,-1} * I_{i} * T_{i}$ & - & - & - & - & 3.986 \\
Random intercept & - & - & - & - & 4.101 \\
\hline
\end{tabular}

The dependent variable is the natural logarithm of the traded number of stocks as reported in the XETRA-OTC data. The sample includes all German stocks that are constituents of the HDAX index between 2009 and 2015. It includes 103,386 observations for 806 dividend events by 155 firms. Due to missing values not all 829 dividend events in the data are included. $D_{i, d}$ takes a value of unity on day $d$ before or after the ex-dividend date. $I_{i}$ is a binary indicator that equals unity in the case of taxable dividends and zero in the case of withholding-tax-free dividends. $T_{i}$ is a binary indicator that takes value unity for observations during the cum-ex period from January 2009 to December 2011, and zero in the post period, i.e., in the years 2012 to 2015. Regression coefficients result from pooled OLS regressions (column (1)), fixed-effects (column (2)) and random-effects regressions (columns (3) to (5)). Specification (5) allows for event-specific deviations from the average cum-ex effect on days -2 and -1 (random slopes). The variances of the random intercept and slope effects are reported at the bottom of the table. The employed estimation method, ordinary least squares, without (OLS) and with fixed effects (OLS(FE)), generalized least squares (GLS(RE)) with random effects, or mixed effects maximum likelihood (ML(ME)), and the use of Mundlak terms in random effects regressions are noted in the table. Cluster-robust standard errors (clustered at dividend-event level) are in parentheses. Asterisks denote statistical significance at the $0.01(* * *)$ levels

\subsection{Robustness checks}

The above findings for the number of stocks traded are obtained using a difference-in-difference approach. Hence, the estimates distinguish between treatment and control groups based on the difference in the number of stocks traded between taxable dividends and tax-exempt dividends and distinguishing events that take place within and after the cum-ex period. Therefore, general increases in trading volumes around ex-dividend dates are removed from the estimates.

But depending on the motives of trading around ex-dividend dates other than cum-ex trading, composition of treatment and control groups might differ, which 


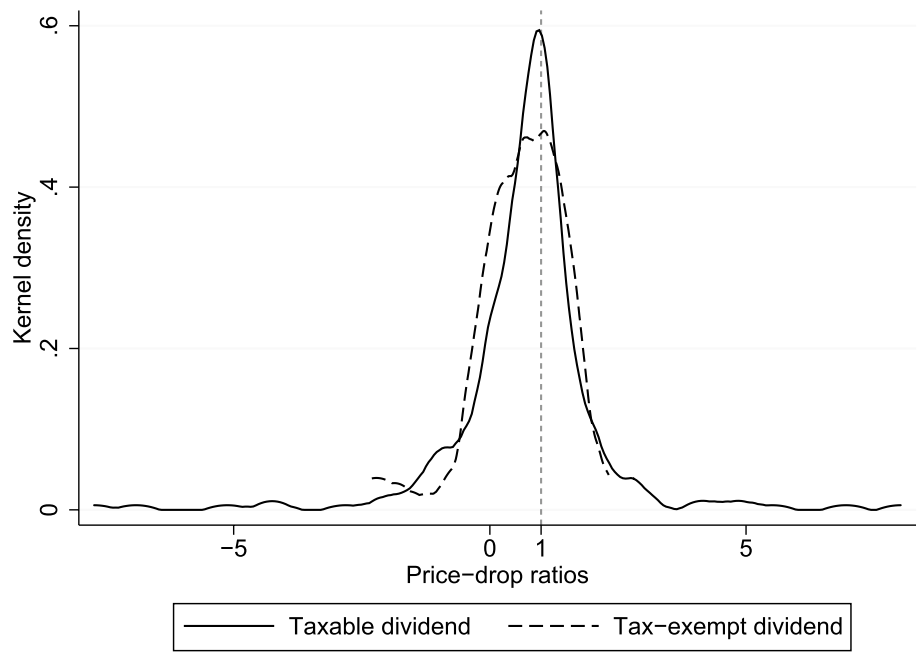

Fig. 5 Price/Drop Ratios, cum-ex period (2009-2011). Note The graphs depict kernel-based estimates of the distributions of PDRs of both stocks with taxable dividends (solid line) and withholding-tax-exempt dividends (dashed line) in the cum-ex period. Epanechnikov kernel densities

could result in biased estimates. In fact, the literature on trading around ex-dividend dates suggests that the volume of transactions might be positively related to the dividend yield (e.g., Karpoff and Walkling 1990; Michaely and Vila 1995; Haesner and Schanz 2013; Henry and Koski 2017). The literature also discusses the role of transaction costs for the trading volume around ex-dividend dates (e.g., Lakonishok and Vermaelen 1986; Karpoff and Walkling 1990; Haesner and Schanz 2013).

As a robustness check, therefore, we introduce as an additional control variable the dividend yield of the respective event. Moreover, since the transaction cost might vary with this indicator, we also include the market capitalization of the respective stock (before the event).

The dividend yield and market capitalization of the respective stock at the dividend event may also be related to the profitability, risks and costs associated with cum-ex trades. For instance, it seems possible that cum-ex trades are concentrated on high-dividend-yield events and on stocks with large market capitalization. Therefore, in the robustness checks, we also include interaction terms between these indicators and the cum-ex effects associated with the last 2 days before the ex-dividend date.

The results of these robustness checks are provided in Appendix. Table A.3 reports the estimates of the interaction terms between the dividend yield and the two indicators capturing the cum-ex effects. ${ }^{30}$ While the results support a positive effect

\footnotetext{
${ }^{30}$ Note that we have scaled the dividend yield such that it captures the deviation from the sample average.
} 
Table 3 Regression results: ex-dividend date price/drop ratios

\section{(1)}

(2)

\begin{tabular}{lllll}
\hline Dividend, Div $_{i}$ & $0.977 * * *$ & $(0.07)$ & $0.994 * * *$ & $(0.07)$ \\
Taxable dividend, $I_{i}$ & 0.159 & $(0.16)$ & 0.172 & $(0.16)$ \\
Cum-ex period, $T_{i}$ & $-0.109 *$ & $(0.06)$ & 0.042 & $(0.19)$ \\
Div $_{i} * I_{i} * T_{i}$ & 0.001 & $(0.23)$ & 0.031 & $(0.24)$ \\
Div $_{i} * T_{i}$ & $0.236^{*}$ & $(0.14)$ & 0.206 & $(0.16)$ \\
Div $_{i} * I_{i}$ & -0.175 & $(0.15)$ & -0.192 & $(0.15)$ \\
$I_{i} * T_{i}$ & -0.211 & $(0.22)$ & -0.235 & $(0.22)$ \\
Constant & -0.015 & $(0.04)$ & -0.067 & $(0.15)$ \\
$P\left(\right.$ Div $\left._{i}<1\right)$ & 0.350 & & 0.466 & \\
$\mathrm{~N}$ & 811 & & 811 & \\
\hline
\end{tabular}

The dependent variable, $\mathrm{PD}_{i}$, is the drop in the stock price from the dividend date (day -1) to the ex-dividend date (day 0 ) in euros as reported in the XETRA data. The sample includes all dividend payments of German stocks that are constituents of the HDAX index between 2009 and 2015. Due to missing values not all 829 dividend events in the data are included. Dividends paid from current profits are subject to withholding tax (taxable dividend, $I_{i}=1$ ), dividends from capital reserves are tax exempt $\left(I_{i}=0\right) . T_{i}$ is unity for dividend payments in the cum-ex period from January 2009 to December 2011 and zero in the post period from January 2012 to December 2015. $P\left(\operatorname{Div}_{i}<1\right)$ provides $P$ values for testing whether the slope parameter for the dividend is less than 1 . Regression coefficients result from OLS regressions (1) and OLS regressions with year dummies (2). Cluster-robust standard errors (clustered at the stock-level) are presented in parentheses. Asterisks denote statistical significance at the $0.01(* * *)$ and $0.10(*)$ levels

of the interaction, the point estimates for the basic cum-ex effect turn out to be very similar to the above findings.

Table A. 3 reports the estimates of the interaction terms between the market capitalization and the two indicators capturing the cum-ex effects. ${ }^{31}$ Again, we find a positive effect of the interaction, but the point estimates for the basic cum-ex effect turn out to be very similar to the above findings.

\subsection{Implied tax-revenue loss}

To compute the implied magnitude of revenue losses, we use the point estimates of the parameters of Eq. (9) based on XETRA data. The tax-revenue loss in euros caused by cum-ex trading for a dividend event $i$ is estimated according to:

\footnotetext{
${ }_{31}$ We have scaled this indicator such that it measures the percent deviation from the average market capitalization based on the sample average.
} 


$$
\operatorname{Loss}_{i}=\sum_{d=-2}^{-1}\left(\frac{\exp \left\{\widehat{\Omega}_{d}\right\}-1}{\exp \left\{\hat{\Omega}_{d}\right\}}\right) \cdot N_{i, d} \cdot \tau_{w} \cdot D i v_{i}
$$

$N_{i, d}$ is the observed number of stocks traded $d$ days before the dividend event. Div $_{i}$ is the dividend (in euros) per stock associated with event $i . \tau_{w}$ is the withholding-tax rate of $26.4 \%$ levied on the dividend.

If we allow for heterogeneity in cum-ex trading and incorporate event-specific cum-ex effects, the tax-revenue loss in euros caused by cum-ex trading on the 2 days prior to the ex-dividend date for the dividend event $i$ is:

$$
\operatorname{Loss}_{i}=\sum_{d=-2}^{-1}\left(\frac{\exp \left\{\widehat{\Omega}_{d}+\widehat{\Omega}_{d, i}\right\}-1}{\exp \left\{\hat{\Omega}_{d}+\widehat{\Omega}_{d, i}\right\}}\right) \cdot N_{i, d} \cdot \tau_{w} \cdot \operatorname{Div}_{i}
$$

For both measures of the revenue loss associated with a specific dividend event, the total tax loss from cum-ex trading in our sample of stocks that occurred during the cum-ex period is

$$
\text { Total Loss }=\sum_{i} \operatorname{Loss}_{i}
$$

where the sum is taken over all dividend events with taxable dividends in the period between 2009 and 2011. If we rely on the random-effects estimates and use Eq. (11) to evaluate expression (13), we obtain a point estimate of the total tax-revenue loss based on XETRA trading activity of about 167 million euros between 2009 and 2011. Allowing for event-specific cum-ex effects by using Eq. (12), the predicted tax-revenue loss is estimated at about 640 million euros. This higher figure suggests that cum-ex trades focus on events with higher dividends and/or on stocks with a higher number of stocks traded.

These estimates for the revenue losses are based on the empirical findings obtained using the XETRA data. The analysis of XETRA-OTC data also points to cum-ex effects on the number of stocks traded. Using the same methodology we can also compute the revenue losses associated with the cum-ex effects found in the XETRA-OTC data. Even though the effect on the number of stocks traded is found to be much stronger, the baseline number of stocks traded in this dataset is small. Hence, the predicted tax-revenue losses from cum-ex trading via OTC on the XETRA platform are roughly similar to the tax-revenue losses predicted for other types of trades on this platform. More specifically, the corresponding figures point to a loss of 274 million euros between 2009 and 2011, based on the random-effects estimates. If we employ the alternative method, which takes account of event-specific cum-ex effects, we obtain a figure suggesting that cum-ex trades using XETRAOTC amount to a tax-revenue loss of 445 million euros.

Including XETRA-OTC our estimates point to a revenue loss of 1.085 billion euros. While XETRA data cover approximately $60 \%$ of the regular trading activity of German stocks (Gomber 2015), it is unlikely that our data also capture $60 \%$ of cum-ex trading. Since it might be much more prevalent on other platforms, the 
fraction of cum-ex trading captured in our analysis might be much less. Hence, it is difficult to ascertain the total volume of tax-revenue losses from our data.

\section{Conclusions}

This paper explores a form of withholding-tax non-compliance that has recently caused substantial tax-revenue losses in Germany and a number of other countries. Responsible for these losses are so-called cum-ex trades of stocks around ex-dividend dates, which under certain conditions lead to refundable tax credits for dividend taxes that have not been remitted.

We provide a theoretical analysis of traders' incentives with and without illegitimate tax refunds in order to explore the rationale behind non-compliance. More specifically, we examine whether the non-compliance comes from traders searching for and exploiting arbitrage opportunities that arise from a technical defect in the way the withholding tax was being imposed and administered or whether the illegitimate tax credits were obtained by deliberate tax fraud. The theoretical discussion shows that in a standard stock-market equilibrium with an ex-dividend date PDR around unity, the second view is appropriate, since profitable cum-ex trading actually requires both illegitimate tax refunds and collusion.

Given the institutional setting in Germany, the theoretical analysis predicts that transaction volumes of stocks used for cum-ex trades should increase immediately before the ex-dividend date of a stock. Since cum-ex buyer and seller need to collude, however, the trades are unlikely to affect the market prices of stocks around ex-dividend dates.

Using transaction data for the German stock market, we tested these predictions. Consistent with the collusion hypothesis, we do not find effects on stock-market prices. We find, however, that the number of stocks traded does in fact increase significantly before the ex-dividend date-only for stocks with taxable dividends and before the change in withholding taxation that stopped the issuance of illegitimate tax credits became effective. This indicates that the increases are, in fact, driven by cum-ex trades. The empirical magnitudes are substantial. Using XETRA data we find an average increase in the number of stocks traded by about $38 \%$ on the last day before the ex-dividend date. For XETRA-OTC data, which reports over-the-counter trades, the average increase is about $304 \%$.

To assess the quantitative magnitude of the effects on the number of stocks traded, we calculated the implied tax-revenue losses due to cum-ex trading. Depending on the empirical specification, the point estimates vary between about 0.441 billion euros for regular XETRA trading and as much as 1.085 billion euros including XETRA-OTC. This number is much lower than the tentative estimate of 7.2 billion euros provided by Spengel et al. (2017). Their estimates are, however, based on very different data and capture the period from 2005 to 2011, while our data only cover the 3 years from 2009 to 2011. Moreover, given the efforts of cum-ex traders 
to conceal their transactions, it seems likely that a substantial part of cum-ex trading took place at other trading venues. Hence, our estimates should not be taken to verify the existing estimates of total tax-revenue losses.

The theoretical and empirical findings support the view that withholding-tax noncompliance in the form of cum-ex trades should not be regarded as some type of financial-market arbitrage exploiting imperfections in the administration of the withholding tax. Rather, the non-compliance associated with cum-ex trades is a form of deliberate tax fraud that requires collusion of cum-ex buyer and seller in order to obtain an illegitimate tax credit. It is interesting to note that, similar to the VAT's "missing-trader" fraud, cum-ex tax fraud has emerged in an internationally integrated market environment, where inconsistencies between tax systems are exploited and where lack of information makes effective enforcement difficult.

The academic literature has emphasized that firms often play a very constructive role for tax administration. More specifically, firms serve as fiscal intermediaries providing information as well as remitting withholding taxes (Kleven et al. 2016). An important precondition is that the agent providing information and/or remitting the tax and the agent, who is the statutory bearer of the tax, face difficulties to form a stable collusion. The large tax-revenue losses related to cum-ex tax fraud indicate, however, that cum-ex buyers and sellers trade in an environment where it is relatively easy to collude. This is remarkable, given the regulation and supervision of financial markets and of the agents participating in these markets including banks. At any rate, financial institutions are rather imperfect fiscal intermediaries for dividend taxation. To improve compliance, further action is required that makes it more difficult to collude.

Acknowledgements Open Access funding provided by Projekt DEAL. For helpful comments and discussions, we thank the editor, two anonymous referees, Christine Crozier, Steffen Juranek, Eric Ohrn, Wolfgang Schoen, Christoph Spengel, Robert Ullmann, Johannes Voget, Alfons Weichenrieder, Marco Wilkens and Floris Zoutman as well as participants at the following conferences and seminars: University Augsburg Brownbag Seminar, International Ph.D. Seminar in Banking and Finance, Passau, Annual Congress of the Verein für Socialpolitik 2017, Vienna, Annual Conference of the National Tax Association 2017, Philadelphia, HVB Ph.D. Seminar South Germany, Riederau, CESifo Area Conference on Public Sector Economics 2018, Munich, Norwegian Centre for Taxation's Faculty Seminar, Bergen, Workshop "Enforcing Tax Compliance at the Limits of Third Party Reporting" at Walter Eucken Institut, Freiburg. Furthermore, we thank Torsten Luedecke for sharing his expertise on financial market data. Jan-Luca Hennig provided excellent research assistance. This project has received financial support from the Foundation "Stiftung Prof. Dr. Oec. Westerfelhaus."

Open Access This article is licensed under a Creative Commons Attribution 4.0 International License, which permits use, sharing, adaptation, distribution and reproduction in any medium or format, as long as you give appropriate credit to the original author(s) and the source, provide a link to the Creative Commons licence, and indicate if changes were made. The images or other third party material in this article are included in the article's Creative Commons licence, unless indicated otherwise in a credit line to the material. If material is not included in the article's Creative Commons licence and your intended use is not permitted by statutory regulation or exceeds the permitted use, you will need to obtain permission directly from the copyright holder. To view a copy of this licence, visit http://creativecommons.org/licen ses/by/4.0/. 


\section{References}

Akhmedov, U., \& Jakob, K. (2010). The ex-dividend day: Action on and off the Danish exchange. Financial Review, 45, 83-103.

Arellano, M. (1993). On the testing of correlated effects with panel data. Journal of Econometrics, 59(12), 87-97.

Baker, P. (2015). The BEPS project: Disclosure of aggressive tax planning schemes. Intertax, 43(1), 85-90.

Boerse Frankfurt. (2008). Bedingungen für Geschaefte an der Frankfurter Wertpapierboerse (FWB) vom 15. August 2008, Frankfurt.

de la Feria, R. (2018). Tax fraud and the rule of law. Working Paper, University of Oxford Centre for Business Taxation.

Dhaliwal, D., \& Li, O. Z. (2006). Investor tax heterogeneity and ex-dividend day trading volume. Journal of Finance, 61(1), 463-490.

Elton, E., \& Gruber, M. (1970). Marginal stockholder tax rates and the clientele effect. Review of Economics and Statistics, 52(1), 68-74.

Elton, E., Gruber, M., \& Blake, C. (2005). Marginal stockholder tax effects and ex-dividend-day price behavior: Evidence from taxable versus non-taxable closed-end funds. Review of Economics and Statistics, 87(3), 579-586.

Gomber, P. (2015). Cash equity markets in Germany. Journal of Applied Corporate Finance, 27(4), $75-80$.

Haesner, C., \& Schanz, D. (2013). Payout policy tax clienteles, ex-dividend day stock prices and trading behavior in Germany: The case of the 2001 tax reform. Journal of Business Finance and Accounting, 40(3-4), 527-563.

Hartzmark, S. M., \& Solomon, D. H. (2013). The dividend month premium. Journal of Financial Economics, 109, 640-660.

Henry, T. R., \& Koski, J. L. (2017). Ex-dividend profitability and institutional trading skill. Journal of Finance, 72(1), 461-494.

Johannesen, N. (2014). Tax evasion and Swiss bank deposits. Journal of Public Economics, 111, 46-62.

Johannesen, N., \& Zucman, G. (2014). The end of bank secrecy? An evaluation of the G20 tax haven crackdown. American Economic Journal: Economic Policy, 6, 65-91.

Kalay, A. (1982). The ex-dividend day behavior of stock prices: A re-examination of the clientele effect. Journal of Finance, 37, 1059-1070.

Karpoff, J. M., \& Walkling, R. A. (1990). Dividend capture in NASDAQ stocks. Journal of Financial Economics, 28, 39-65.

Keen, M., \& Smith, S. (2006). Vat fraud and evasion: What do we know and what can be done? National Tax Journal, 59(4), 861-887.

Klautke, T. (2008). Tax policy, corporations, and capital market effects. Dissertation, University of Frankfurt.

Kleven, H. J., Knudsen, M. B., Kreiner, C. T., Pedersen, S., \& Saez, E. (2011). Unwilling or unable to cheat? Evidence from a tax audit experiment in Denmark. Econometrica, 79(3), 651-692.

Kleven, H. J., Knudsen, M. B., Kreiner, C. T., \& Saez, E. (2016). Why can modern governments tax so much? An agency model of firms as fiscal intermediaries. Economica, 83(330), 219-246.

Lakonishok, J., \& Vermaelen, T. (1986). Tax-induced trading around ex-dividend days. Journal of Financial Economics, 16, 287-319.

Madzharova, B. (2013). The effect of a low corporate tax rate on payroll tax evasion. In C. Fuest \& G. R. Zodrow (Eds.), Critical issues in taxation and development. Cambridge, MA: MIT Press.

McDonald, R. L. (2001). Cross-border investing with tax arbitrage: The case of German dividend tax credits. Review of Financial Studies, 14(3), 617-657.

Michaely, R., \& Vila, J.-L. (1995). Investors' heterogeneity, prices, and volume around the ex-dividend day. Journal of Financial and Quantitative Analysis, 30(2), 171-198.

Milanez, A. (2017). Legal tax liability, legal remittance responsibility and tax incidence: Three dimensions of business taxation. OECD Taxation Working Papers, 32.

Mundlak, Y. (1978). On the pooling of time series and cross section data. Econometrica, 46(1), 69-85.

Rau, S. J. (2010). Leerverkäufe und doppelte Anrechnung von Kapitalertragsteuer. DStR, 25, 1267-1271.

Slemrod, J. (2008). Does it matter who writes the check to the government? The economics of tax remittances. National Tax Journal, 61(2), 251-275. 
Slemrod, J., \& Gillitzer, C. (2014). Tax systems. Cambridge, MA: MIT Press.

Special Investigation Committee. (2017). Beschlussempfehlung und Bericht des 4. Untersuchungsausschusses des Deutschen Bundestags nach Artikel 44 des Grundgesetzes. Drucksache 18/12700.

Spengel, C. (2016). Sachverständigengutachten nach §28 PUAG für den 4. Untersuchungsausschuss der 18. Wahlperiode. https://www.bundestag.de/blob/438666/15d27facf097da2d56213e8a09e27008/ sv2_spengel-data.pdf. Last accessed on August 2nd, 2018.

Spengel, C., Dutt, V., \& Vay, H. (2017). Auswertung der Clearstream Beweismittel-Zulieferungen. Auswertung für den 4 . Untersuchungsausschuss der 18. Wahlperiode.

Spengel, C., \& Eisgruber, T. (2015). Die nicht vorhandene Gesetzeslücke bei Cum/Ex-Geschäften. DStR, $52(16), 785$.

Wooldridge, J. M. (2002). Econometric analysis of cross section and panel data. Cambridge, MA: MIT Press.

Yaniv, G. (1988). Withholding and non-withheld tax evasion. Journal of Public Economics, 35(2), 183-204.

Yaniv, G. (1992). Collaborated employee-employer tax evasion. Public Finance-Finances Publiques, $47(2), 312-321$.

Publisher's Note Springer Nature remains neutral with regard to jurisdictional claims in published maps and institutional affiliations. 